\title{
Developing a Deep and Liquid Bond Market Experience of Sri Lanka
}

\author{
K G D D Dheerasinghe*
}

\begin{abstract}
The bond market in Sri Lanka has shown a slow but steady growth since the primary issue of Treasury Bonds that began in 1997. The Primary Dealer System that existed since 1992 provided a sound institutional framework for this growth whilst the Real Time Gross Settlement System and Scripless Securities Settlement System that came into being recently provided further impetus to the development of the bond market. With regular primary issues and secondary market trading in long-term debt, a yield curve emerged in the Treasury Bond market. The existence of a yield curve in the government bond market would encourage issuance of corporate debt as it would provide a bench mark for pricing of corporate debt. The high degree of risks involving settlement and trading in scrip securities and systemic deficiencies were minimized with the introduction of new infrastructure and efficiency in the market operations increased due to scripless trading and electronic on-line settlement in a delivery versus payment environment.

With the increased competition in the market, spreads between buying and selling prices have reduced gradually. This would assist, among other things, in reducing the cost of borrowing to the Government. The large institutional investors have taken the initiative to develop their fund management skills and, with better trading skills of dealers and investors, the market will be increasingly active and even the long-term bonds will become much more liquid instruments in the market.

The organizational and policy related issues, such as the delay in the formation of a public debt management office, large and widening fiscal deficit, debt sustainability and solvency issues, high proportion of short term debt, irregular cash flows, deficiencies in cash management, primitive nature of the corporate debt market and taxation on debt instruments vis-à-vis conventional sources of financing, are the key remaining issues that need to be addressed. (JEL H63, G18)
\end{abstract}

\footnotetext{
* The author wishes to thank Mr. H. R. Khan, Chief General Manager, Internal Debt Management Cell, Reserve Bank of India for his comments on earlier version of this paper.
} 


\section{Introduction}

In Sri Lanka, the need to develop a domestic bond market received increased attention with the introduction of financial sector reforms and re-structuring programmes in recent years. Initiatives have been taken in regard to providing a conducive macro economic policy environment, strengthening the institutional and legal framework, and market infrastructure including payments and settlements systems, thus enabling the issue of more long term debt securities and facilitating their trading in the secondary market, aiming the development of depth of the market and liquidity of long term debt instruments. The experience thus far indicate that this has been a process of undertakings of many complexities involving immense challenges, as some of the problems that inhibit the market development are deep rooted in the economy.

In Sri Lanka, issue of long-term tradable government bonds began in 1997 even though domestic government debt existed since the 1920s. This has provided the opportunity for the investors to place their long term funds on interest bearing long term default risk free government securities whilst providing a long term yield curve which not only would facilitate the trading of long term debt instruments thus enhancing their liquidity, but also would provide a benchmark for pricing of corporate debt instruments. Table 1 below shows the composition of Sri Lanka's bond market, which is dominated by government securities.

\section{Table 1 - Composition of Tradable \& Non-Tradable Debt in Domestic Debt Market}

\begin{tabular}{|c|c|c|c|c|c|c|}
\hline & \multicolumn{2}{|c|}{1997} & \multicolumn{2}{|c|}{2000} & \multicolumn{2}{|c|}{2003} \\
\hline & $\begin{array}{c}\text { Value } \\
\text { (Rs. mn.) }\end{array}$ & $\%$ & $\begin{array}{c}\text { Value } \\
\text { (Rs. mn.) }\end{array}$ & $\%$ & $\begin{array}{l}\text { Value } \\
\text { (Rs. mn.) }\end{array}$ & $\%$ \\
\hline \multicolumn{7}{|l|}{ 1. Tradable Debt } \\
\hline $\begin{array}{l}\text { 1.1 Treasury Bonds } \\
\text { (medium-long term) }\end{array}$ & 10,000 & 2.74 & 204,124 & 33.85 & 483,107 & 50.81 \\
\hline $\begin{array}{l}\text { 1.2 Treasury Bills (short } \\
\text { term } 91-364 \text { days) }\end{array}$ & 114,996 & 31.55 & 134,996 & 22.39 & 219,295 & 23.06 \\
\hline 2. Non-Tradable Rupee Loans & 239,475 & 65.70 & 263,888 & 43.76 & 248,414 & 26.13 \\
\hline Total & 364,471 & 100.00 & 603,008 & 100.00 & 950,816 & 100.00 \\
\hline
\end{tabular}

Source: PDD, Central Bank of Sri Lanka

The corporate bond market has remained insignificant over the years whilst government debt market has grown leaps and bounds. The corporate debt issues, mainly debentures with maturities of five years and less, have been issued mainly by financial institutions to enable them to some extent to reduce their asset/liability mismatch. Long term debt issued by non-financial corporates has been negligible. Issues relating to developing the corporate bond market are mentioned in this paper wherever reference is deemed necessary.

The rapid growth of government debt, on the one hand, may be viewed from large and growing fiscal deficit of successive budgets and the governments resorting to more and more domestic borrowing to mobilize resources to finance their expenditure programmes. Quite apart from developing the debt market, growing public debt that has reached 105 per cent of GDP since 2002 has caused increased concerns of debt sustainability in the long run. 


\section{Table 2 - Distribution of Bonds by Issues}

\begin{tabular}{|c|c|c|c|c|c|c|}
\hline & \multicolumn{2}{|c|}{1997} & \multicolumn{2}{|c|}{2000} & \multicolumn{2}{|c|}{2003} \\
\hline & $\begin{array}{c}\text { Value } \\
\text { (Rs. mn.) }\end{array}$ & $\%$ & $\begin{array}{c}\text { Value } \\
\text { (Rs. mn.) }\end{array}$ & $\%$ & $\begin{array}{c}\text { Value } \\
\text { (Rs. mn.) }\end{array}$ & $\%$ \\
\hline 1. Government & 10,000 & 78.94 & 125,322 & 98.39 & 214,797 & 98.63 \\
\hline 2. Corporate & 2,668 & 21.06 & 2,056 & 1.61 & 2,979 & 1.37 \\
\hline Total & 12,668 & 100.00 & 127,378 & 100.00 & 217,776 & 100.00 \\
\hline
\end{tabular}

Source: PDD, Central Bank of Sri Lanka

Note: Corporate debt issues are for 1998, 2000 and 2002

The Fiscal Management Responsibility Act (FMRA) 2002 provides for some provisions, although non-binding, to address the concerns of fiscal deficit and debt/GDP ratios but a fundamental question may arise as to the practicability of achieving the targets set by this legislation. ${ }^{1 /}$

\section{Government Debt Management Framework}

The responsibility of managing government debt is vested with the Central Bank of Sri Lanka (CBSL) in terms of the Monetary Law Act (MLA) No. 58 of 1949. The issuance of government debt instruments, such as Rupee Loans (RL), Treasury Bonds (T Bonds) and Treasury Bills( T. Bills) are provided for in the Registered Stock and Securities Ordinance (RSSO) No. 7 of 1937 and subsequent amendments made in 1949, 1995 and 2003 and Local Treasury Bills Ordinance (LTBO) (Chapter 287) of 1941 and subsequent amendments made in 1992, 1995 and 2003 respectively. The framework outlined by these legislations does not provide an objective of public debt management. However, conventionally, it has been recognized and established that primary objective of public debt management to be "to ensure that the government's financing needs and its payment obligations are met at the lowest possible cost over the medium to long run, consistent with a prudent degree of risk" (World Bank 2001). The government is presently considering the option of establishing a Public Debt Management Office (PDMO) and consequently, as part of this exercise, a more definite policy for debt management with a clearly defined objective may be formulated.

At present, the annual borrowing programme of the government through issuance of domestic debt securities is formulated by the Public Debt Department (PDD) of the CBSL subject to the borrowing requirement and the limit set by the annual Appropriation Act approved by the parliament. The limit for T.Bill issues during the fiscal year is also incorporated into the Appropriation Act, which authorizes the government borrowing for financing the budget. The modus operandi of issuing and servicing of domestic government debt, i.e. T. Bills and T. Bonds, is stipulated in LTBO and RSSO, and the CBSL undertakes these functions as the agent of the government as provided for in the MLA.

1/ A main feature in the FMRA 2003 is the stipulation of medium term fiscal strategy targets. The budget deficit has to be reduced to $5 \%$ of GDP by 2006 and maintained at this level thereafter. This was $8.9 \%$ in 2002 . As a percentage of GDP, public debt should not exceed $85 \%$ in 2006 and $60 \%$ in 2013. In 2002, this ratio was 105.1\%. 
The government also mobilizes foreign debt for the purpose of financing the budget, subject to the provisions of the Foreign Loans Act No. 29 of 1957, which authorizes the President to enter into agreements with foreign lenders. The servicing arm for negotiating foreign loans has been the External Resources Department (ERD) who maintains relevant records and a database shared with the PDD for the purpose of servicing all foreign loans, which have been contracted mostly under bilateral, and multi lateral loan agreements with concessional terms. The Government of Sri Lanka has raised debt in the international capital markets only on two occasions in the past i.e., in 1997, a Floating Rate Note was issued for US\$ 50 million and, in 2003, a Syndicated Loan of US\$ 100 million was raised. The high concessionality (approximately 98 per cent) of foreign debt liability of the government and long repayment periods of such borrowing, which constitutes approximately 45 per cent of the government debt outstanding, have not caused any concern of high cost of debt service and sustainability at present. The prevailing capital account controls would prevent any pressure on account of the country's foreign debt on the exchange rate and the country's foreign reserves.

Since recent years, the domestic debt market is characterized by more long term bonds for meeting the government's capital expenditure requirements, enabling the investors to place their savings or other liquid funds in fixed income bearing securities, developing the intermediaries to bring together investors to subscribe to the issuances, providing infrastructure to build up a conducive environment for securities transactions and ensuring legal title to securities and settlement of transactions whilst providing transparency and greater price discovery. Coupled with these, a regulatory framework has been provided and strengthened. As a result, market structures have become increasingly competitive with low transaction costs.

\section{Government Fiscal Operations and Borrowing Requirement}

The central government budget, which represents approximately 87 per cent of public expenditure and 94 per cent of revenue, provides a clear overview of total government finances. The Provincial Councils (created in 1988) operates with large budget deficits and their expenditure programmes depend largely on the grants provided by the central government. The other local authorities, such as Municipal Councils, Urban Councils and Pradeshiya Sabhas, though large in numbers, do not constitute a significant proportion of public expenditure, have their expenditure programmes financed by their revenue resources other than certain expenses, such as salaries and wages, and are to some extent independent of the central government budget.

The budgets of successive governments since Sri Lanka regained independence in 1948 , except on two occasions in the 1950s, have shown increasingly widening deficits requiring increased borrowing by the government for financing.

The deteriorating government revenue and growing expenditure mainly on account of defense purposes, interest payments on government debt and government employees' wage bill have, though as a proportion of GDP has reduced but increased in absolute terms, necessitated the increased borrowing for financing the deficit. The resulting concerns, particularly in respect of debt sustainability and fiscal solvency, may be observed in respect 
Table 3 - Budget Deficits and Borrowing Requirement (As a \% of GDP)

\begin{tabular}{lccc}
\hline & $\mathbf{1 9 9 7}$ & $\mathbf{2 0 0 0}$ & $\mathbf{2 0 0 3}$ \\
\hline Total Revenue & 18.5 & 16.8 & 15.7 \\
Total Expenditure & 26.4 & 26.7 & 23.7 \\
Overall Deficit & -7.9 & -9.9 & -8.0 \\
Financing & 7.9 & 9.9 & 8.0 \\
Foreign & 1.9 & 0.4 & 2.9 \\
Domestic & 3.4 & 9.4 & 4.5 \\
Other/Privatization & 2.5 & 0.1 & 0.6 \\
\hline
\end{tabular}

Source : Central Bank of Sri Lanka

Table 4 - Domestic Financing of Fiscal Deficit

(billions)

\begin{tabular}{lrrr}
\hline (Rs. Billions) & $\mathbf{1 9 9 7}$ & $\mathbf{2 0 0 0}$ & $\mathbf{2 0 0 3}$ \\
\hline By instruments & 39.6 & 118.5 & 79.7 \\
Long term Bonds & 10 & 90.6 & 137.1 \\
Short term Bills & -4.7 & 6.1 & 14.9 \\
Non-tradable Securities & 33.5 & 1.8 & -39.3 \\
US $\$$ denominated Bonds & - & - & -15.2 \\
Other Loans & -9.5 & 15.8 & -18.3 \\
Long terms Bonds & & & \\
By Source & 39.6 & 118.5 & 79.7 \\
Bank Borrowing & -2.2 & 56.5 & -20.9 \\
Non-Bank Borrowing & 41.8 & 62 & 100.7 \\
\hline
\end{tabular}

Source: Central Bank of Sri Lanka

Table 5 - Government Domestic Debt Indicators

\begin{tabular}{lccr}
\hline & $\mathbf{1 9 9 7}$ & $\mathbf{2 0 0 0}$ & $\mathbf{2 0 0 3}$ \\
\hline Govt. Debt/GDP & 85.8 & 96.9 & 105.9 \\
Domestic Debt/GDP & 43.6 & 53.8 & 57.9 \\
Total Debt Service/GDP & 9.45 & 14 & 19.6 \\
Domestic Debt Service/Govt. Revenue & 36.6 & 67.9 & 108.0 \\
Domestic Debt Service/Govt. Expenditure & 23.4 & 31.6 & 46.9 \\
Domestic Interest/GDP & 5.5 & 4.9 & 6.4 \\
Domestic Interest/Govt. Current Expenditure & 27 & 24.5 & 39.9 \\
\hline & & \multicolumn{2}{c}{ Source: Central Bank of Sri Lanka }
\end{tabular}


of debt/GDP ratio of $105.9 \%$ in 2003 which is significantly higher from that of $85.8 \%$ in 1997. The domestic debt component of this ratio was $52.9 \%$ in 2003 and $42.1 \%$ was foreign debt over $98 \%$ of which constitutes concessional debt raised from multilateral and bilateral sources at low rates of interest with long repayment periods. The sustainability issue, therefore, may be over stated by the overall debt/GDP ratio of $105.9 \%$.

\section{Money Market Liquidity and Funding Cost of Long Term Bonds}

Buyers of long-term bonds may be identified as investors who have access to funds, which can be locked in for a long period of time and bond dealers whose business is trading in bonds for making profits. The former category largely includes passive investors who buy and hold their securities until maturity but, depending on their fund management and trading skills, would engage in buying and selling activities in the secondary market. However, their main source of income is usually the interest income earned from the capital invested. The bond dealers, on the other hand make their profits from trading their securities and their profits would largely depend on the cost of funding of their portfolios, which are turned over a number of times until such time the security remains in the inventory. Funding of long-term bonds by dealers, therefore, take place through borrowing at the short end of the market through instruments, such as repos, and hence lower overnight and inter-bank rates enable the dealers to maintain a positive carry in their portfolios. To this extent, lower and stable short term interest rates with adequate money market liquidity are important in maintaining stability in the long term bond yield rates.

Figure-1

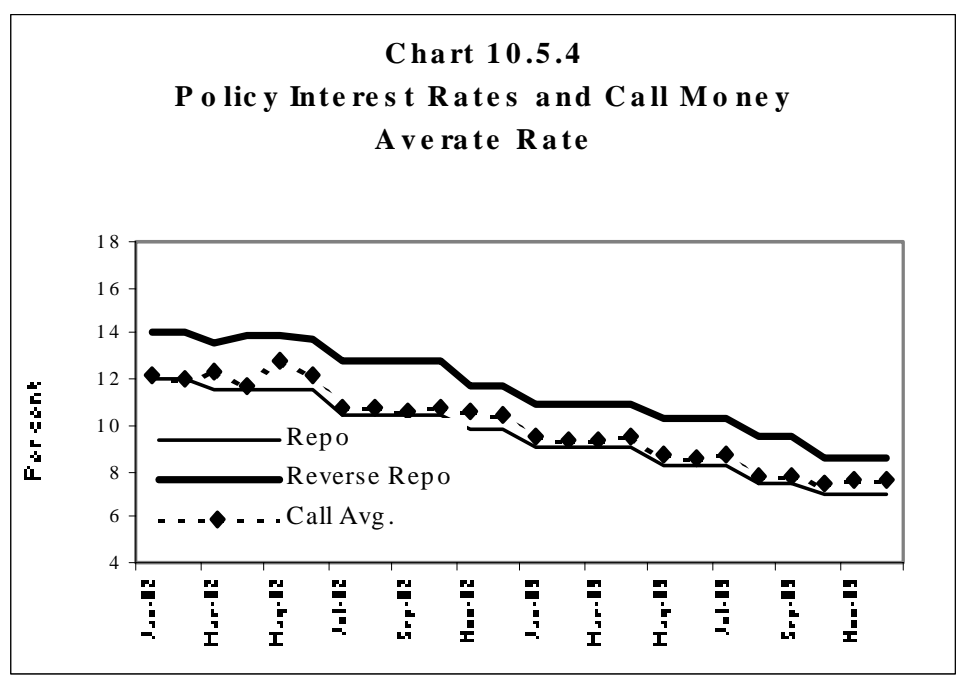

Source: Central Bank of Sri Lanka 
Several significant measures have been taken, particularly during the past two decades, to facilitate money market operations. The CBSL introduced a window for discounting and rediscounting of T. Bills in 1981.2/

This enabled both sale and purchase of T.Bills by the CBSL through transactions initiated by banks, depending on their liquidity requirements. The CBSL, in 1993 and in 1995, introduced a repo window and a reverse repo window respectively, enabling primary dealers and banks to take overnight (sometimes term repos) with the CBSL for purposes of either parking their daily excess liquidity (repo) or obtaining liquidity (reverse repo) from the CBSL.

The CBSL took a further step towards market orientation of monetary policy operations and to improve their effectiveness with the introduction of active Open Market Operations (OMO), which has built in incentives to encourage competition in the money market and for participating institutions to improve their liquidity management. The system operates within an explicit monetary target and a monetary policy framework. The OMO are conducted to ensure the achievement of reserve money targets while maintaining inter-bank over night interest rates on which the impact of monetary policy decision is reflected almost instantaneously, stable within a narrow range. The main features of this system include(a) an interest rate corridor (b) daily auction of either repos or reverse repo to maintain the interbank rate stable within the corridor, (c) standing facilities and (d) outright buying/selling of T.Bills/ Bonds at the discretion of the CBSL to either inject or absorb long term liquidity.

Besides the benefits of market based OMO, this system which was in operation since March 2002 has brought in less volatility in interest rates, improvement in liquidity need estimation and liquidity management practices and finally to reduce cost of funds. The stability of short term interest rates, better liquidity management and reduced cost of funds for market participants have impacted favourably on the long term bond market, particularly attributable to the resulting positive carry due to lower cost of borrowing

\section{Debt Issuance Programme and Market Access}

The annual borrowing requirement through the government securities programme is disaggregated into amounts that can be raised from each instrument and this exercise will be based on resources available for mobilization according to market preference of tenor and other attributes of the instruments that are used. As a debt management strategy, the issuance in recent years was mostly confined to medium to long-term coupon bonds. A monthly programme containing details of each issue with maturities, coupon rates and amounts is issued to the market. Each individual issue is separately announced to the market in advance and these announcements include the details of the proposed issue and key statistics relating to the previous issue. The issuance methods include mainly auctions and sometimes placements. The auctions are accessible to primary dealers, Employees Provident Fund (EPF) and Central Depository system of Colombo Stock Exchange (CDS/CSE). Immediately after the auction is finalized, an announcement is made to the market on the amount issued under each maturity (in the case of T. Bills) and respective weighted average yield

2/ The CBSL engages in open market operations with licensed commercial banks and primary dealers. The primary dealers were appointed by CBSL in 1998 and prior to this, the counterparties for open market operations transactions have been licensed commercial banks. 
rates. The successful bidders at the auction will receive their securities credited to the participants' accounts in the CDS of the SSS System at the prices at which the bids have been accepted, i.e. securities are issued at multiple prices. The auctions are conducted via CBSL net which is a LAN connecting all primary dealers and the CBSL. The securities are credited to the CDS accounts of the primary dealers on the settlement ate on $\mathrm{DvP}_{2}$ basis. ${ }^{3 /}$

The daily cash flow forecast of the Treasury together with the borrowing programme is discussed at monthly meetings of the Domestic Debt Management Committee (DDMC) meeting, which comprises representatives of heads of relevant departments of the CBSL, such as Public Debt, Economic Research and Domestic Operations and Treasury officials from the State Accounts and Fiscal Policy departments. The recommendations of the DDMC are made to the Governor for approval before being announced to the market. ${ }^{4 /}$

Preparation of the monthly borrowing programme is based on volume of maturing debt, which are seldom redeemed and mostly rolled over sometimes with different maturities and coupon rates, maturity profile of existing debt (mainly to satisfy the need for avoiding any bunching of future debt maturities), duration of funds requirement of the Treasury for determination of the type of instrument to be used and sentiments and perceptions of the market. Weekly meetings are held with primary dealers in order to feel the pulse of market sentiments and perceptions. This process is further facilitated by regular i.e., daily, weekly and monthly, information flows between the PDD and primary dealers. Regular meetings are also held with large institutional investors and this interaction helps in understanding investor preferences for timing of different instruments. On daily and weekly basis, information pertaining to market activities, such as daily buying and selling prices and volumes of transactions, is issued to the market, viz. primary dealers, banks and other financial institutions through email, and electronic and print media. The sharing of information in this manner has helped in ensuring transparency and effectiveness of the debt issuance programme.

\section{Debt Market Infrastructure}

The infrastructure framework includes, Online Electronic Bidding System (OEBS), Real Time Gross Settlement (RTGS) System, Scripless Securities Settlement (SSS) System, Central Depository System (CDS), Bloomberg Bond Trading System (BBTS) of primary dealers and Colombo Stock Exchange Trading System and its Central Depository (CSE/CDS). The OEBS has been in operation since 1998. This system replaced the paper based bidding at primary auctions that began in 1984. The OEBS facilitates transmission and processing of bids received at auctions and providing information to the Tender Committee. The auction results are also issued to the primary dealers through this system immediately after the decision is made by the Tender Committee. The data generated in the Front Office of the PDD, based on this system, is shared with the Middle Office for updating its database and Back Office for payments and settlements.

3/ According to $\mathrm{DvP}_{2}$ model of settlement at primary issues of government securities, payments due from primary dealers are netted against payments due to primary dealers.

4/ The responsibility of the agency function of public debt management is vested with the Monetary Board, which authorizes the annual government securities programme and determination of the coupon rate and maturity of securities is delegated to the Governor. Hence, each week, the government securities programme requires approval of the Governor before being issued to the market. 
The SSS System and CDS were introduced in February 2004. Prior to this, securities were issued in scrip form and trading in government securities was exposed to a high level of risk associated with scrip securities.

\section{A. Real Time Gross Settlement (RTGS) System}

The RTGS System enables electronic, i.e. instantaneous transfer of large value and time critical payments between participants. The settlement is on a real time gross basis. Once entries are recorded in the System, the transaction becomes final and irrevocable. The participants of the system include the CBSL, Licensed Commercial Banks (LCBs), Primary Dealers (PDs) and two other institutional participants, namely the Employees' Provident Fund (EPF) and Central Depository System of the Colombo Stock Exchange (CSE/CDS).

The efficiency that has resulted from the RTGS System has benefited the market by way of immediate transfer of funds, reduced inconvenience due to elimination of the use of cheques in transactions with the CBSL, improvement in liquidity management as the time lag of transactions being reduced significantly, benefits of manifold increase in the turnover and volume of transactions, and access to interest free Intra-day Liquidity Facility (ILF) provided by the CBSL. There are significant benefits to investors, such as that associated with the reduced cheque float, timely receipt of proceeds due to them from counterparties, and the ability to make time critical payments.

\section{B. Scripless Securities Settlement (SSS) System}

Under the SSS System, all T. Bills and T. Bonds are issued in scripless form. A title registry, i.e. CDS of government securities, is maintained by the CBSL. This is known as LankaSecure. The SSS System is interfaced with the RTGS System to enable delivery of securities against payment. Therefore, the participants of the SSS System are same as those of the RTGS System. Each participant of the SSS System is given a browser workstation. The mode of communication in the RTGS/SSS Systems is the SWIFT messaging system. Each series of securities, i.e. each maturity of T. Bills and T. Bonds issued at each primary issue, will have a corresponding International Securities Identification Number (ISIN). All securities in the SSS System and the CDS will be identified by these numbers.

Table 6 - Transaction Numbers \& Volumes of the SSS System

\begin{tabular}{|c|c|c|}
\hline Period & Number of Transactions & Volume (Rs. mn.) \\
\hline February - 2004 & 5,696 & $451,719.01$ \\
\hline March - 2004 & 14,037 & $503,271.56$ \\
\hline April - 2004 & 11,500 & $523,349.47$ \\
\hline May - 2004 & 11,833 & $597,637.00$ \\
\hline$\overline{\text { Total }}$ & 43,066 & $2,106,977.04$ \\
\hline
\end{tabular}

Source: CDS, PDD, Central Bank of Sri Lanka

LankaSecure, the CDS or the title registry is located in the PDD. Each participant has a securities account for its own account trading purposes. In addition to own accounts, 
primary dealers and licensed commercial banks maintain accounts on behalf of their customers. Investors in government securities, i.e. individuals, corporates and institutional investors, have the flexibility to maintain any number of accounts with any one or more primary dealer or a commercial bank or a combination of both.

\section{Table 7 - Growth of Depository Accounts of CDS}

\begin{tabular}{llr}
\hline Period & & No. of A/Cs \\
\hline February & -2004 & 10,893 \\
March & -2004 & 12,483 \\
April & -2004 & 13,781 \\
May & -2004 & 13,846 \\
\hline
\end{tabular}

Source: CDS, PDD, Central Bank of Sri Lanka

The SSS System will facilitate four types of secondary market transactions. They are:

- Outright buying and selling, i.e. Delivery versus Payment (DvP) and Receive versus Payment.

- Delivery free and receive free transactions.

- Repo and reverse repo transactions.

- Repositioning of securities.

T. Bill and T. Bond auctions will continue to be conducted electronically based on EOBS. The quantity and value of securities bought by each primary dealer is transmitted to the SSS System automatically immediately after finalizing the primary auction. Settlement of securities by the CBSL with primary dealers at the primary auctions takes place on DvP basis. The DvP Model 2, i.e. receipts are netted against payments, is used for this purpose.

The SSS System provides $\mathrm{T}+0$ to $\mathrm{T}=10$ settlement. Whenever a settlement involving a transfer of funds takes place, the System will verify the buyer's account for funds. The settlement will go through only if the buyer's account has sufficient funds for the transaction. The full amount of the transaction has to be settled at once. No partial settlement is allowed by the System. Liquidity for settlement is available to primary dealers and banks for intra-day on a collateralized basis and free of charge. Securities taken for the ILF is valued at official prices issued by the CBSL on a daily basis.

Payment instructions are automatically generated by the System at the maturity of securities and also when interest payments are due. All payments due to participants and their clients are made to the participants' RTGS accounts. It is the responsibility of the participant, i.e., primary dealer/bank to credit their customer accounts on the same day on which the settlement has been made. Monthly statements are issued by the CDS confirming the transactions that have taken place during the month and the balance at end of the month.

The existing T. Bills and T. Bonds held by the market will be dematerialized. This will be necessary for the SSS System to operate effectively. The conversion from scrip to scripless will be optional and not mandatory. However, holders of scrip securities will not have the advantage of using the system. Notices have been published in the government gazette and newspapers informing the public of the conversion process. 
The benefits of the SSS System in improving efficiency and minimizing the risks in the debt market may be seen as follows:

- Investors' risks associated with holding and trading paper-based securities are totally eliminated.

- Investor will not experience the inconveniences as in the case of dealing with paper-based securities, such as safekeeping, endorsement and physical delivery, in the event of a transaction.

- $\quad$ The System will operate on DvP basis, i.e. securities will be delivered through the SSS System immediately upon confirmation of payment through the RTGS System.

- Investors will receive securities on the same day of the issue unlike in the case of scrip securities at present, which involves a time lag.

- The CDS will maintain separate accounts for each individual investor and will function as the custodian of all government securities, thus eliminating the investor's risk of physical holding and minimizing the cost of safekeeping.

- Investors will not run the risk of either failing to re-invest the funds or collect maturity proceeds or coupon interest payments, as the CDS will automatically generate the relevant reports regarding all such payments due to the investor well in advance.

- The efficiency of the System would result in saving of time in executing a trade and will improve liquidity in the government debt securities market.

- The primary dealers can reduce the margins between their buying and selling prices due to reduced cost of intermediation and enhanced liquidity.

- The System will also facilitate the surveillance of the market and supervision of primary dealers.

The primary dealers and licensed commercial banks are the only dealer direct participants (who are permitted to maintain customer accounts) of the RTGS and SSS System with whom all other investors/dealers in government securities have to maintain their securities accounts. Thus, the CDS of government securities maintained by the CBSL is a customerbased depository. The settlement of securities in the SSS System is on DvP basis subject to confirmation of funds transfer through the RTGS System and hence the settlement risk of counter party is minimized. 


\section{Bloomberg Bond Trading System}

The primary dealers began to use the BBTS since November 2003 and this replaced the traditional telephone based trading that had hitherto been used for trade matching. In addition to screen based trading, the analytics available in the BBTS is being used by the PDD for monitoring the primary dealer activities. The BBTS, among other things, has encouraged primary dealers to quote two-way prices for benchmark securities in making the market for government securities. It is, however, quite premature to measure the impact of the BBTS on the bond market, particularly due to the short period of time it has been in operation and unfavourable market conditions that prevailed in the recent months attributable to political instability demanding a higher risk premium on long term bond yields.

\section{Participation of Colombo Stock Exchange in Government Debt Market}

The CDS/CSE was admitted to the RTGS and SSS Systems of the CBSL as a direct participant in March 2004. This has enabled the trading of the beneficial interest of government securities at the CSE. The trading members of the CSE has been encouraged to trade in government securities through the Debt Trading System (DEX) of the CSE and benefits of this may be seen as greater price discovery and transparency in the government debt securities market.

The CSE/CDS has direct access to the primary auctions of T. Bills and T. Bonds as a designated non-dealer bidder $^{5 /}$ on a competitive basis and this serves the purpose of continuous and regular availability of securities to the DEX system.

\section{Organization of Primary Market and Primary Dealer System}

Primary dealers have exclusive access to primary auctions of government securities with the exception of access given to the EPF and CDS/CSE. The participation of the EPF at shortterm T.Bill auctions has been insignificant due to its interest in the long end of the market and this is evident from the composition of the EPF portfolio, which is heavily biased for longterm bonds. The EPF, the largest single fund holding an asset base of Rs. 350 billion (US $\$ 3.5$ billion), has been developing its fund management and trading skills since recent years. The access provided to CSE/CDS enables direct purchase of securities from primary auctions to provide a mix of products at the CSE trading floor and spread the risk between equity and fixed income bearing instruments.

\section{A. Primary Dealers}

Primary dealers were first appointed in 1992 and have undergone changes at several stages since then, particularly in 1994, 2000 and 2002. There are two distinct categories of primary dealers currently operating, i.e. primary dealer companies whose activities are only confined to government securities trading and primary dealer units of licensed commercial banks. Minimum capital and capital adequacy requirements have been stipulated by the CBSL on

5/ The EOBS distinguishes between designated direct dealer bidder and designated non-dealer bidder. The former category denotes all primary dealers and the latter category includes any non-primary dealer entity for whom access is permitted. 
both categories of primary dealers. Each primary dealer has to satisfy a minimum participation level of $10 \%$ at primary auctions. The minimum infrastructure requirements, managerial and technical skills, and regulatory compliance are to be satisfied by all primary dealers as stipulated in regulations, directions and guidelines issued from time to time by the CBSL. Primary dealers also have to comply with a Code of Conduct issued by the CBSL.

\section{B. Primary Issuance Strategy}

The methods of primary issues include auctions (multiple price), placements and tap issues. The auction is the most common method of issue in the case of T. Bills and T. Bonds. Placements are made mainly in the case of T. Bonds where buyers agree on terms of offer, i.e. maturity and price after negotiations with PDD. The price at which securities issued on placements is based on either the current secondary market price or recent most weighted average auction price in order to ensure transparency. The Rupee Loans, which are transferable only by registration (non-tradable), are issued on tap basis. This instrument had been heavily used in the past for mobilizing funds mainly from captive investors, i.e. state sector funds. However, with gradual market orientation of debt issuances, non-tradable Rupee Loans were issued very seldom in recent years. Since 2003, Rupee Loans that were issued with the call option in the past have been redeemed and this process resulted in more issuances of tradable long-term debt and eventually Rupee Loans will get phased out in a few years' time.

\section{Licensing and Regulating Primary Dealers}

The primary dealers are licensed/regulated by the CBSL. At present, there are 12 primary dealers, 9 of which are primary dealer companies and 3 are primary dealer units of commercial banks. Criteria for appointment of primary dealers have been issued in 2000 by a gazette notification together with other regulations promulgated by the Hon. Minister of Finance under the provisions of the RSSO and LTBO.

A supervision manual for primary dealers was issued in June 2000 and, coupled with this, a supervision unit was set up in the PDD. Primary dealers are subject to continuous surveillance on a regular basis and periodic on-site examinations. The supervision and regulatory framework is outlined by a number of directions and guidelines issued by the Public Debt Department within the regulations issued under the RSSO and LTBO. The directions cover all areas of activities of primary dealers, such as, segregation of proprietary government securities accounts, capital adequacy, financial statements, custodial holdings, new products, establishment of branches, repo and reverse repo transactions, two-way prices, minimum capital requirement, forward rate agreements and interest rate swaps, minimum subscription levels at primary auctions, short selling of securities and special risk reserve.

\section{Secondary Market}

The main players in the secondary market for government securities are primary dealers, banks and a few institutions, such as EPF, ETF (Employees Trust Fund) and insurance companies. Until recently, when securities were issued in scrip form, market activities were 
restricted mainly to repo transactions due to the time lags in settlement and other practical difficulties involved in endorsement and physical delivery of securities as well as potential settlement risk. However, with the issue of scripless securities, genuine buy and sell transactions are growing significantly.

\section{A. Secondary Market Dealers}

In addition to primary dealers and licensed commercial banks, who are major players in the market, there are a large number of institutions, corporates and both small and large financial institutions who operate in the secondary market for government securities. The large and wide participation has enhanced the liquidity of the government securities market. Primary dealers, who quote their buying and selling prices on competitive basis with relatively thin spreads, have encouraged small players in the market to be actively involved in secondary market activities.

\section{B. Yield Curve}

With the commencement of T. Bond issuance since 1997, the debt market became familiar with long term instruments. However, up until 2003 when the first 10-year bond was issued, all T. Bond issues were confined to a maturity range of 2-6 years. The gradual increase in bond prices and increased appetite for longer term instruments enabled the issue of 15 and 20 year T. Bonds towards the latter part of 2003.

With the stretching of maturities up to 20 years, the market began to develop its preference on a few benchmark securities, which, at present, are seen as 3 year and 5 year bonds. The long term yield rates that fell below $7.0 \%$ towards the $3^{\text {rd }}$ quarter of 2003 reversed its trend and the inverted yield curve that prevailed has got reversed with this development into a sharply upward slopping one with a high risk premium being placed at the long end, a spread of 250 basis points from about $7.50 \%$ at the short end to $9.00 \%$ at the long end, e.g. spread of 5 year maturity.

Figure 2 - Yield Curve

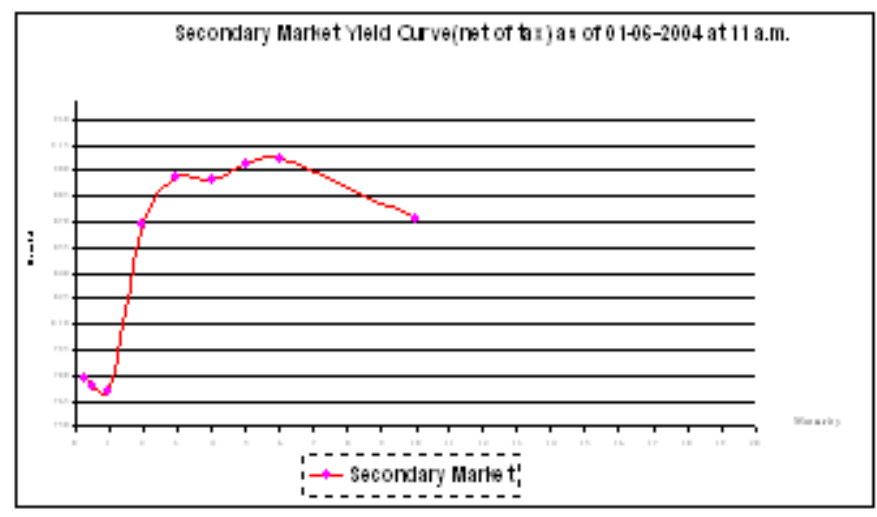

Source: Central Bank of Sri Lanka 
The Corporate bond issuance in recent years have given the option of either a fixed rate or a floating rate to the investors and, in the latter option, a risk premium of 150 to 200 basis points over and above the short term T. Bill rate has been offered. More buyers have opted for the floating rate implying their risk perception in the volatile interest rate scenario. No Corporate debt issuances thus far have offered a fixed yield option benchmarked with long term T. Bond yield rates, implying investor preference for floating rates to long term fixed rates.

\section{Ownership Structure of government Securities}

An interesting observation that can be made on the composition of the ownership of government securities is the phenomenal growth of ownership by private individuals which has more than doubled in 2003 as compared to 1997, the year in which long term T. Bonds were first introduced. There has been a gradual decline in the ownership of securities by the banking sector. The holdings of the CBSL, mainly resulting from its monetary policy operations have declined to little more than two per cent of the total outstanding in 2003 from a high proportion of 2000 when the market suffered a liquidity shortage, requiring the CBSL to take reverse repos with banks and primary dealers.

Table 8 - Ownership of Government Securities

\begin{tabular}{|c|c|c|c|c|c|c|}
\hline & \multicolumn{2}{|c|}{1997} & \multicolumn{2}{|c|}{2000} & \multicolumn{2}{|c|}{2003} \\
\hline & $\begin{array}{c}\text { Value } \\
\text { (Rs. mn.) }\end{array}$ & $\%$ & $\begin{array}{c}\text { Value } \\
\text { (Rs. mn.) }\end{array}$ & $\%$ & $\begin{array}{c}\text { Value } \\
\text { (Rs. mn.) }\end{array}$ & $\%$ \\
\hline 1. Domestic Debt & 387,740 & 50.75 & 676,660 & 55.52 & $1,019,968$ & 54.72 \\
\hline 1.1 Banking Sector & 100,536 & 13.15 & 199,030 & 16.33 & 228,411 & 12.25 \\
\hline Central Bank & 19,770 & 2.59 & 97,778 & 8.02 & 44,587 & 2.39 \\
\hline Commercial Banks & 80,766 & 10.57 & 101.252 & 8.31 & 183,824 & 9.86 \\
\hline 1.2 Non-Bank Sector & 287,202 & & 477,630 & & 791,557 & \\
\hline Savings Institutions & 63,028 & 8.25 & 87,263 & 7.16 & 138,939 & 7.45 \\
\hline Sinking Funds & 100 & 0.01 & 100 & 0.01 & 100 & 0.01 \\
\hline Insurance Funds & 9,292 & 1.22 & 18,969 & 1.56 & 24,828 & 1.33 \\
\hline Provident \& Pension Funds & 144,406 & 18.90 & 218,615 & 17.94 & 333,289 & 17.88 \\
\hline Official funds & 15,438 & 2.02 & 24,640 & 2.02 & 40,739 & 2.19 \\
\hline Private Individuals & 48,638 & 6.37 & 120,116 & 9.86 & 246,209 & 13.21 \\
\hline 1.3 Other & 6,302 & 0.82 & 7,927 & 0.65 & 7,453 & 0.40 \\
\hline 2. Foreign Debt & 376,331 & 49.25 & 542,040 & 44.48 & 843,883 & 45.28 \\
\hline Total & 764,071 & 100.00 & $1,218,700$ & 100.00 & $1,863,850$ & 100.00 \\
\hline
\end{tabular}

Source: Central Bank of Sri Lanka

With the non-bank sector holdings by institutional investor categories, such as, saving institutions, sinking funds, insurance, provident/pension funds and other funds have gradually reduced, although marginally in the past may be attributable to the growth in the ownership of securities by private individuals. The popularity of government securities that is gathering momentum among individual investors is encouraging from the point of view of broad basing the ownership which would at least to some extent, result in increasing the depth of the market whilst assisting in reducing distributional inequalities as small time savers in low income groups receive a significant proportion of interest income resulting from public debt. 


\section{Taxation Policy and Government Securities Market}

Based on the principle that taxation affects allocative efficiency, the government was mindful of minimizing the impact of taxation on government securities. The capital gains tax on government securities was done away with since 1996 and this has eliminated a main impediment to developing the secondary market. Interest income from government securities is currently liable for $10 \%$ withholding tax collected up front at source. The government securities are, therefore, issued to the market by the CBSL as a tax paid instrument.

\section{Summary}

Several initiations have been taken in recent years to provide an environment conducive for developing the bond market through financial sector reforms and restructuring programmes. These include, the introduction of RTGS and SSS Systems including a CDS for government securities, OEBS to improve primary market infrastructure, BBTS for trading in the secondary market, code of conduct for primary dealers, issue of long-term government bonds with 10, 15 and 20 year maturities and developing a long-term benchmark yield curve. These improvements have, among other things, provided greater price discovery and transparency to the government bond market.

With the improvement of monetary policy operations resulting from more market oriented system of conducting OMO has brought in stability in the short end of the market and this has assisted the bond dealers to maintain a positive carry in their portfolios whilst longterm bonds that were made available have attracted long-term investors, thus strengthening the maturity structure of public debt, in addition to impacting favourably on cost of debt to the government.

The widening fiscal deficit, mainly due to deteriorating revenue and rising expenditure, has to some extent been arrested during the last two years, mainly attributable to reduced interest cost on public debt. The high debt/GDP ratio may be overstated, as $45 \%$ of public debt is foreign debt contracted at concessional terms with long repayment periods. Against this background, increased domestic debt maturity with more long-term bonds being issued at higher prices than earlier has brought in stability into public debt management whilst benefiting from greater depth and increased liquidity of the market. 


\section{References}

Asian Development Bank (2002), "Bond Market Development in East Asia : Issues and Challenges" , (Preliminary Draft) Regional Economic Monetary Unit, Manila, Philippines.

Central Bank of Sri Lanka, Annual Reports, Central Bank of Sri Lanka, Colombo.

Chul Woo Park (1999), "Maturity Structure of Public Debt and Expected Bond Returns", Journal of Banking and Finance.

Dheerasinghe, KGDD (1997), “Treasury Bonds”, The Chartered Accountant Vol.32 No.1., The Institute of Chartered Accountants of Sri Lanka, Colombo, Sri Lanka.

(1997), "Treasury Bonds", The professional Banker, Vol.32, No 2, The Association of Professional Bankers, Colombo, Sri Lanka.

(1997), “Treasury Bond Programme - Trends during the First Few Months of Implementation” People's Bank, Vol. 23, No. 9, Colombo Sri Lanka.

(1997), Government Debt Securities Market - Current Status and Future Prospects", Banker's Journal, Volume XVIII No.3, “Institute of Bankers of Sri Lanka, Colombo, Sri Lanka.

(2002), "Bond Market in Sri Lanka”, Round Table on Debt Market (key-note address), Business Asia, Mumbai, India.

(2003), "Scripless Securities System \& Central Depository System, Question \& Answer”, Central Bank of Sri Lanka, Colombo, Sri Lanka.

Guidotti Pablo E and Kumar Manmohan S. (1991), "Domestic Public Debt of Externally Indebted Countries”, Occasional Paper 80, IMF, Washington DC.

Jayawardena A.S. (2002), “Challenges in Developing a Deep and Liquid Bond Market”, Kay note address made at National Conference on Fixed Income Securities, Colombo, Sri Lanka.

Sharma Krishnan (2000), “The Underlying Constraints on Corporate Bond Market Development in South East Asia”, United Nations Department of Economic and Social Affairs.

Tobin James (1971), “An Essay on the Principles of Debt Management”, Economics Vol.1. pp. 378-455.

World Bank / IMF Developing Government Bond Markets (2001), A Handbook, Washington DC.

Yun-Hwan Kim ( 2001), “Government Bond Market Development in Asia”, Asian Development Bank, Philippines. 